\title{
Att kommunicera känsla
}

\author{
Dialogdikter i stormaktstidens gravskrifter över kvinnor
}

\author{
Hwad höres här för Grååt? hwad Suckan Sorg och Jämmer? \\ Hwad ynkeligit Lååt? hwad är thet I upstämmer? \\ Hwad tillra nedh för Kin / så heta Tårar mång? \\ Hwad jämrar sig Ehrt Sin och siunger Sorgesång? ${ }^{1}$
}

RÖSTEN SOM TALAR I DIKTCITATET ovan tillhör köpmanshustrun Maria Lorentzdotter Gerdt, som dog i barnsäng I678 och begravdes i Åbo domkyrka. Dikten trycktes i en gravskrift som sattes ihop av vänner och bekanta till henne och hennes make, Herman Thorwöst. Enligt titelbladet har dikterna tillkommit "Then salige Matronan till Ihogkommelse sampt hennes i Sorgen qwarbleffne Man til någon Tröst och skyldigh Tienst”. Den ovan citerade dikten är skriven av studenten Gustavus G. Gronovius. ${ }^{2}$ I diktens början sörjer maken sin hustru och beklagar hennes plötsliga bortgång. Han önskar att han ännu en gång fick tala med henne, även om han vet att hans önskan kommer för sent. I dikten kan ändå sådant ske som inte kan hända i verkligheten. Hustrun svarar honom, och verkar förundrad över hans känslosamma reaktion, som om hon inte helt skulle ha insett sin egen bortgång.

Artikeln är skriven med forskningsfinansiering från Konestiftelsen.

I. Gustavus G. Gronovius, gravdikt i Klage-Gråå; Öfwer Ehreborne Gudsfruchtige och myckit Dygderijke Matrona Hust. Maria Lorentz Dotter Gerdt, Åbo: Peter Hansson I678.

2. Gronovius var kapellansson och gav sig också själv in på prästbanan. Hans tillfällesdikter kom till under studieåren vid I670-talets slut och I68o-talets början. Kyösti Väänänen, "Gustavus Gabrielis Gronovius", Turun hiippakunnan paimenmuisto I554-I72I, Studia Biographica 9, Helsinki: Suomalaisen Kirjallisuuden Seura, http:// urn.fi/urn:nbn:fi:sks-thp-00084I (hämtad 24/II 2020). 
Många av stormaktstidens gravdikter är likt den ovan citerade väldigt känslosamma. Dikterna både skildrar och uttrycker olika känslor, som sorg, saknad, ensamhet och förtvivlan. De beskriver människor som sörjer och låter dem tala. Vid sidan av sorgen är trösten - som framgår ur titelbladet till Maria Lorentzdotter Gerdts gravskrift - ett centralt element i gravdiktningen. Dikterna syftar till att trösta och ingjuta hopp i de sörjande.

Syftet med denna artikel är att studera hur tal och tilltal används för att uttrycka och kommunicera känsla i gravdikter. I materialet ingår gravdikter skrivna på svenska och utgivna i Finland och Sverige under tidsperioden $1657^{-1706 . ~ J a g ~ i n t r e s s e r a r ~ m i g ~ s p e c i e l l t ~ f o ̈ r ~ d i k t e r ~ s o m, ~}$ likt dikten till Maria Lorentzdotter Gerdt, gestaltar en speciell typ av talsituation: en dialog mellan maken och hans döda hustru. Med andra ord är det fråga om dikter som beskriver fiktiva talsituationer och använder sig av ett rolljag, även om de är skrivna med anledning av verkliga händelser och hänvisar till verkliga historiska personer.

Att dialogformen använts i gravdikterna har noterats i den tidigare forskningen. Gunnar Castrén ser likheter mellan gravdiktningens dialoger mellan makar och "bröllopsdikternas dialog mellan sponsus och sponsa". ${ }^{3}$ Den nylatinska bröllopsdiktningens dialoger har behandlats av Raija Sarasti-Wilenius. ${ }^{4}$ Arvid Hultin hävdar att det finns ett släktskap mellan den liturgiska växelsången, responsorierna och dialogformen, men att de poetiska dialogerna också hade andra litterära förebilder. ${ }^{5}$ Till exempel i Carl Fehrmans studie över litteraturens dödsbilder behandlas dialogdikter från medeltiden och r6oo-talet $\mathrm{i}$ vilka döden samtalar med en människa. ${ }^{6}$ Toini Melander har skrivit om en finskspråkig dialogdikt från $\mathrm{I} 673$, som skildrar samtalet mellan döden och en ung student, och klarlagt diktens person- och kulturhistoriska bakgrund samt dess kopplingar till ars moriendi-traditionen. ${ }^{7}$

3. Gunnar Castrén, Stormaktstidens diktning, Helsingfors: Helios I907, s. I33.

4. Raija Sarasti-Wilenius, "Henkilökirjallisuus", Tuija Laine (toim.), Vanhimman suomalaisen kirjallisuuden käsikirja, Helsinki: Suomalaisen Kirjallisuuden Seura I997, s. 230-232.

5. Arvid Hultin, Den svenska vitterheten i Finland under stormaktstiden, Helsingfors: Svenska litteratursällskapet i Finland I904, s. XCV.

6. Carl Fehrman, Diktaren och döden. Dödsbild och förgängelsetanke i litteraturen frän antiken till I70o-talet, Stockholm: Albert Bonniers förlag 1952.

7. Ars moriendi-litteraturen undervisade i konsten att förbereda sig inför döden och 
I en artikel om isländsk begravningspoesi från I6oo-talet tar Pórunn Sigurðardóttir fasta på konversationens och tilltalets roll i dikterna. Hon ser diktandet som ett led i sorgeprocessen; att dikta om den avlidna eller tilltala denna i en dikt är ett sätt att försöka komma till rätta med förlusten. ${ }^{8}$

Vid sidan om sin känslosamhet utmärks gravdiktningen av talets och talarens centrala roll. Både dikternas poetiska utformning och den uppfattning om känslor som dikterna uttrycker präglas av retoriken. Tillfällesdiktarna var skolade i retorik, och detta innebär att de diktade i tro på att deras ord kunde påverka läsarnas eller åhörarnas åsikter och känslor. ${ }^{9}$ Därför är dikternas sätt att framställa tal och tilltal centrala för diskussionen om hur känslor skildras i tillfälleslitteraturen.

Artikeln tar avstamp i retoriken. Jag utgår från att dikterna stöder sig på retorikens uppfattningar om hur språk förmedlar och uppväcker känsla. Därutöver tillämpas litteraturvetenskapliga analysmetoder. Också inom lyrikteori diskuteras dikter ofta som tal och som kommunikation. En central fråga i lyrikforskningen har varit i vilken grad läsaren eller publiken är delaktig i dikten. Om vi uppfattar dikten som tal, ett hurdant tal är det fråga om? Har dikten en monologisk eller dialogisk karaktär? ${ }^{10}$

Dikterna som utgör materialet för denna studie är skrivna i dialogform. Det betyder att de har två eller i vissa fall flera talare, som turvis får komma till tals. Dialog i lyriken handlar ändå inte bara

dö en värdig död. Toini Melander, Suomalaista tilapäärunoutta Ruotsin vallan ajalta II, Helsinki: Suomalaisen Kirjallisuuden Seura I94I, s. I2-I9.

8. Porunn Sigurðardóttir, "Does genre matter? Reading and interpreting seventeenth-century Icelandic funeral poetry", Arne Jönsson, Valborg Lindgärde, Daniel Möller \& Arsenii Vetushko-Kalevich (red.), Att dikta för livet, döden och evigheten. Tillfällesdiktning under tidigmodern tid, Göteborg \& Stockholm: Makadam förlag 2020, s. I89-204.

9. Stina Hansson," Bröllopslägrets skald och bårens". En studie i Lucidors tillfällesdiktning, Göteborg: Göteborgs universitet 1975, s. 39, 47; Thomas O. Sloane \& Walter Jost, "Rhetoric and poetry", The Princeton Encyclopedia of Poetry and Poetics, Princeton \& Oxford: Princeton University Press 20I2, s. II75-II78.

Io. W.R. Johnson, The Idea of Lyric. Lyric Modes in Ancient and Modern Poetry, Berkeley: University of California Press I982, s.3-23; William Waters, "Address", The Princeton Encyclopedia of Poetry and Poetics, s. 6-8; Heather Dubrow, The Challenges of Orpheus. Lyric Poetry and Early Modern England, Baltimore: Johns Hopkins University Press 2008, s. 56-59; Jonathan Culler, Theory of the Lyric, Cambridge, Massachusetts: Harvard University Press 2015, s. Io9-I25, https://doi.org/I0.4I59/978067442578I. 
om mängden talare, och egentligen känneteckas all litteratur av interaktion, av dialogicitet. ${ }^{11}$ Dialogicitet inbegriper olika former av interaktion. Enligt Katja Seutu kan lyrikens dialogicitet komma till uttryck till exempel genom diktens sätt att framställa tal och genom växelverkan mellan olika dikter eller olika delar av en enskild dikt. Dialogiciteten kan också uttryckas genom interaktion med externa diskurser eller genom diktens sätt att etablera en kontakt till läsaren. ${ }^{12}$ Alla dessa former av interaktion är relevanta också med tanke på de dialogformade gravdikterna.

Ett känslosamt innehåll kan fungera som ett sätt att skapa interaktion mellan dikten och dess läsare. Textens affektivitet innebär att texten uttrycker en viss hållning eller ger uttryck för en ståndpunkt, vilket för läsaren skapar möjligheter att ta ställning, hålla med, reagera med medkänsla eller distansera sig från det som texten uttrycker. ${ }^{13}$ Begreppet affektivt skript (affective script) har använts för att åsyfta allmänt vedertagna normer som formar människornas känsloliv inom ett samhälle eller en kultur. Sarah McNamer har i sin forskning använt begreppet i mer konkret bemärkelse för att utforska diktens förmåga att skapa och befästa modeller för hur känslor upplevs och uttrycks. Hon menar att en text, till exempel en dikt, kan fungera som ett affektivt skript, ungefär som ett känslomanuskript eller en känslomanual. ${ }^{14}$ Uppfattningen om dikten som ett affektivt skript kan jämföras med Barbara Herrnstein Smiths tanke om dikten som en föreställning som fulländas först genom läsarens deltagande. ${ }^{15}$

I den här artikeln studerar jag dialogens affektiva potential och dialogen som en form av interaktion mellan talaren och den tilltalade, men också mellan dikten och läsaren. Efter en presentation av mate-

II. Marianne Shapiro \& Michael Shapiro, "Dialogism and the addressee in lyric poetry", University of Toronto Quarterly 61, I992:3; Culler, Theory of the Lyric, s. I4; Dubrow, The Challenges of Orpheus, s. 69-7i.

I2. Katja Seutu,"Runouden dialogisuudesta", Aino Koivisto \& Elise Nykänen (toim.), Dialogi kaunokirjallisuudessa, Helsinki: Suomalaisen Kirjallisuuden Seura 2013, s. $297^{-299 .}$

13. Ibid., s. 308-309.

I4. Sarah McNamer,"The literariness of literature and the history of emotion", PMLA I3O, 2015:5, s. I433-I442.

15. Barbara Herrnstein Smith, On the Margins of Discourse. The Relation of Literature to Language, Chicago \& London: University of Chicago Press 1978, s. 36-37. 
rialet och stormaktstidens gravdiktning diskuterar jag dialogdikternas tilltal och talarroller. Därefter undersöks dialogernas sätt att gestalta känsla. Tyngdpunkten i artikeln ligger på en lyrikteoretisk analys av dikternas talare och talsituationer.

\section{GRAVDIKTER ÖVER KVINNOR}

Gravdikten var I6oo-talets dominerande diktform. Även om det inte finns exakta uppgifter om mängden gravdikter som skrevs eller utgavs, var genren uppenbarligen välkänd och vanlig. ${ }^{16}$ Gravdikterna var ett centralt inslag i de högre ståndens sorge- och begravningsritualer under stormaktstiden. Ofta skrevs de, som gravskriften till Maria Lorentzdotter Gerdt, av vänner, bekanta eller släktingar, även om dikter också kom till på beställning. Speciellt högt uppsatta personer kunde uppvaktas av skribenter som önskade visa upp sitt kunnande och söka gunst hos samhällets makthavare. ${ }^{17}$

Dikterna gavs ut i separattryck som kunde innehålla en eller flera dikter. Ofta trycktes dikterna tillsammans med likpredikan. ${ }^{18}$ Maria Lorentzdotter Gerdts begravning i Åbo r678 uppmärksammades med två olika skrifter. Den ena har titeln Lijk-Predikning öfwer den fordom Ehreborna / Gudfruchtigh och Dygderijka unge Matrona, Hustru Maria Lorentzdotter Gertes [...] Jordefärd och Begraffning, ${ }^{19}$ och innehåller likpredikan och den så kallade personalian, en kort biografi över den

16. Per S. Ridderstad, "Vad är tillfällesdiktning? En kort översikt", Personbistorisk Tidskrift 1980:3, s. 25-4I; Daniel Möller, Fänad i helgade grifter. Svensk djurgravspoesi I670-I760, Lund: Ellerströms 20II, s. I7; Pirkko Lilius, Språkval och ordval i tillfällesdiktningen i Finland I700-I749, Helsingfors: Svenska litteratursällskapet i Finland 1994, s. 54-55.

I7. Bo Bennich-Björkman, Författaren i ämbetet. Studier i funktion och organisation av författarämbeten vid svenska hovet och kansliet 1550-1850, Uppsala: Svenska bokförlaget I970, s.75-76, 88-9I; Ann Öhrberg, Vittra fruntimmer. Författarroll och retorik hos frihetstidens kvinnliga författare, Hedemora: Gidlunds förlag 200I, s. 89-9I; Ridderstad, "Vad är tillfällesdiktning?", s. 25-4I.

I8. Fehrman, Diktaren och döden, s. 253-254; Ridderstad, "Vad är tillfällesdiktning?", s. $25-4 \mathrm{I}$.

19. Lijk-Predikning öfwer den fordom Ehreborna / Gudfruchtigh och Dygderijka unge Matrona, Hustru Maria Lorentzdotter Gertes [...] Jordefärd och Begraffning, Åbo: Johan Winter 1678. Se också Toini Melander, Personskrifter hänförande sig till Finland 1562-I7I3. Bibliografisk förteckning, Helsingfors: Helsingfors universitet I95I, s. 273. Nr 7I5. 
döda som lästes upp vid begravningen i Åbo domkyrka, samt fem svenskspråkiga gravdikter och ett epitafium på latin. Den andra gravskriften har titeln Klage-Gråä öfwer Ehreborne / Gudsfruchtige och myckit Dygderijke Matrona Hustr. Maria Lorentz Dotter Gerdt [... $]^{20}$ och innehåller fyra dikter, av vilka en är skriven på latin och de övriga på svenska. Det kan påpekas att Gustavus G. Gronovius, den redan nämnda författaren till dialogdikten som citerades i början, medverkar i båda gravskrifterna.

Dikterna i mitt material är alla skrivna till minne av kvinnor. Författarna är män, vilket beror på att tillfällesdiktandet ofta var en syssla för studenter och utbildade män inom statsförvaltningen, akademin eller prästeståndet. ${ }^{21}$ Dialogformen verkar ha varit populär speciellt i gravskrifter över kvinnor, även om den också kunde tillämpas för andra adressater. Gravskriften till studenten Matthias Amnander, som dog i Åbo I699, innehåller till exempel en dialog mellan den avlidne och hans föräldrar. ${ }^{22}$ Oftast verkar adressaterna ändå ha varit gifta kvinnor, som i de sex dialogdikter som kommer att analyseras närmare $i$ artikeln. Adressaterna ${ }^{23}$ är:

- Sara Danielsdotter, hustru till ränt- och proviantmästaren i Viborg, Johan Olofsson Unger. Dog vid 3r års ålder r657 i Viborg.

- Catharina Wernle, hustru till borgmästaren i Åbo, Nicolai Lietzen. Dog som 29-åring I657.

- Margareta Knutsdotter, hustru till kyrkoherden i Kronoby,Jacobus Brenner. Dog vid 65 års ålder 1668.

- Maria Lorentzdotter Gerdt, hustru till köpmannen Herman Thorwöst. Dog vid 29 års ålder I678 i Åbo.

20. Gronovius, gravdikt i Klage-Grååt öfwer Ehreborne / Gudsfruchtige och myckit Dygderijke Matrona Hustr. Maria Lorentz Dotter Gerdt [...]. Se Melander, Personskrifter, s. 273. Nr. 716.

2I. Stina Hansson, Svensk bröllopsdiktning under I6oo- och I7oo-talen. Renässansrepertoarens framväxt, blomstring och tillbakagång, Göteborg: Göteborgs universitet 2oII, s. 464-466; Lilius, Språkval och ordval, s. I23, I37-I38; Ridderstad, "Vad är tillfällesdiktning?"

22. I. Wetterberg, gravdikt i Sorge-Blommer wid den Ehreborne och Wällärde Studiosi Matthiae Amnandri Jordefärd och Begrafningz-Act, Johan Winter: Åbo I699.

23. Den person som dikten är skriven till kallas adressat eller föremål. Om terminologin, se Lilius, Språkval och ordval, s. 23. 
- Beata Margareta Uggla, gift med Erik Giös till Nygård. Dog som 33-åring 1690 och begravdes i Pojo kyrka.

- Anna Walstenia, hustru till kyrkoherden i Loimijoki, Matthias Rungius. Dog vid $7 \mathrm{I}$ års ålder 1706.

Diktföremålen representerar präste- och borgarståndet samt adeln. Deras gravskrifter ingår i Nationalbibliotekets samlingar, som innehåller kring 3000 personskrifter från svenska tiden. ${ }^{24}$

Tillfällesdikterna utgår från en för alla skribenter gemensam repertoar. Det var inte författarens sak att hitta på nya former eller nytt innehåll, utan att ur de existerande litterära förråden välja ut det som passade bäst för tillfället. Den här principen för litterärt skapande är kännetecknande för den diktning som Stina Hansson kallar repertoardiktning, till skillnad från den verkdiktning som blev dominerande $\mathrm{i}$ det litterära systemet $\mathrm{i}$ samband med romantikens inbrott och den muntliga kulturens tillbakagång. ${ }^{25}$

Repertoaren utgör grunden för den litterära kommunikationen i gravdikterna. Det här innebär att dialogformen med dess talarroller, diktens medel att uttrycka känsla och de tankar om sorg och tröst som dikten ger uttryck för är element som ingår i gravdiktningens repertoar. Centrala frågor blir då hur tillfällesdiktarna använder sig av dialogformen i sina dikter, hur dialogen samverkar med diktens struktur och innehåll och på vilket sätt dialogen används för att kommunicera känsla till läsaren.

Den sorg och saknad som uttrycks i I6oo-talets gravdikter speglar rådande kulturella uppfattningar om vad sorg var, hur den kändes och på vilket sätt den skulle uttryckas. Det är alltså inte diktarens personliga sorg som skildras. Krav på personlighet, originalitet och

24. Personskrifterna är digitaliserade. Se Nationalbibliotekets digitala samlingar, https://digi.kansalliskirjasto.fi/collections? $i d=468.0 \mathrm{~m}$ samlingens innehåll, se Raimo Ojanperä, "Ruotsin vallan aikaisen suomalaisen henkilökirjallisuuden kokoelma”, Helsingin yliopiston kirjaston tiedotuslehti I992:8, s. I76-I8I.

25. Begreppsparet repertoardiktning och verkdiktning kommer från Horace Engdahl och har vidareutvecklats av Stina Hansson. Horace Engdahl, Den romantiska texten. En essä i nio avsnitt, Stockholm: Bonniers I986, s. 37-38; Stina Hansson, Från Hercules till Swea. Den litterära textens förändringar, Göteborg: Göteborgs universitet 2000, s. II-I3; Hansson, Svensk bröllopsdiktning, s. I5-I8. 
äkthet ingår inte i tidens litteraturuppfattning. Däremot hade den tidigmoderna diktaren enligt Lars Gustafsson som uppgift att vara en "rollgestaltare" - han skulle anpassa sig till den rådande situationen och adressatens eller mottagarens förväntningar, samt i sitt diktande gestalta allmänt erkända, konventionella förhållningssätt. ${ }^{26}$

\section{Tilltal: LovPrisning, KLAgAN OCH TRÖST}

När den 7I-åriga Christina Bergenstierna dog på Åland år 1703 tog den sjuttonåriga Johannes Gezelius, son till biskopen i Åbo, ${ }^{27}$ avsked av sin farmor i en dikt som avslutas med följande rader:

Så såf Fru Fahr Mohr sött / tills åter I uhr Grafwen

Med glädie stigen up / då I haa whilat ut

Ehr matta kropp och been / och så det goda slut

Som I med Christlig Troo af Gud förwärfwat hafwen. ${ }^{28}$

Dikten till Christina Bergenstierna slutar alltså med att den döda tilltalas, men den inleds med ett tilltal till döden:"Tu Död / tu skrämmer them som för tin ankomst rädas." Dikten handlar om hur döden är förskräcklig för dem som lever okristligt, men "söt" för dem "som uthi Gudlighet från thenna jorden faar". Christina Bergenstierna kan, enligt författaren, se fram emot uppståndelsen med tillförsikt.

Det är vanligt att gravdikter innehåller hälsningar till den avlidna eller till de sörjande. I gravskriften tillägnad köpmanshustrun från Åbo, Maria Lorentzdotter Gerdt, vänder sig skribenten Johannes

26. Lars Gustafsson, "Litteratur och miljö", Stellan Dahlgren, Allan Ellenius, Lars Gustafsson \& Gunnar Larsson (red.), Kultur och sambälle i stormaktstidens Sverige, Stockholm: Wahlström \& Widstrand i967, s. III.

27. Johannes Gezelius (I686-I733), senare biskop i Borgå, kallades Nepos (sonson), för att man lättare skulle kunna skilja mellan honom och hans far och farfar med samma namn. Pentti Laasonen, "Gezelius, Johannes (Nepos)", URN:NBN: fi:sls-4475-I4I692895708I, Biografiskt lexikon för Finland, elektronisk utgåva, Svenska litteratursällskapet i Finland 20I4, www.blf.fi.

28. Johannes Gezelius, gravdikt i The Andelige Strijdzmäns rätta tillstånd [...] LijkPredijkan öfwer [...] Fru Christina Bergenstierna, Åbo: Johan Winter I704. 
Flachsenius ${ }^{29}$ till hennes make med ett tilltal som ska illustrera hustruns roll i hushållet:

Hör til o THORWÖST god! hwar är tin Frögd tin Ähra:

Hwar är tin Ögnelust / hwar är tin Maka kiähra:

Hwar är then tigh kär had' och älskad' aldramäst

Then tigh födt wackra Barn / them tuchtat och der näst

Hwar är then tigh godh hielp giorde uthi tin handell

och med ett gott Förstånd beprydde all tin Wandell [...]

Tin Säng hon synes toom / titt Huus och nästan öde

Wisst har här fahrit fram den grym' oblide Döden. ${ }^{30}$

I dikten har tilltalet en annorlunda roll än i vardaglig kommunikation; just tilltalet har ofta ansetts vara en central metod i lyriken för att skapa en kontakt till läsaren. Oberoende av vem som är föremål för diktens direkta tilltal är det egentligen läsaren dikten vill kommunicera med, hävdar Jonathan Culler, som kallar denna form av poetisk interaktion för triangulärt anförande (triangulated address). ${ }^{31} \mathrm{I}$ hans modell är talaren, den tilltalade och läsaren viktiga parter i diktens kommunikation. Alla former av tilltal kan då läsas som indirekt tilltal till läsaren. Tilltalets uppgift kan vara att mana läsaren till etiska eller moraliska ställningstaganden beträffande talaren, adressaten, tilltalets stil eller diktens innehåll. I gravdikterna kan tilltalet vara ett medel att sätta fokus på föremålet för dikten och beskriva henne. Tilltalet är inte i första hand riktat till Christina Bergenstierna eller till Herman Thorwöst, utan till publiken, till läsarna eller åhörarna.

Gravdikten byggdes traditionellt upp kring tre centrala element. En gravdikt skulle lovprisa den avlidna (laus), beklaga dödsfallet (luctus) och trösta de sörjande (consolatio). ${ }^{32}$ Lovprisandets rötter finns i den

29. Johannes Flachsenius var matematiker, professor i teologi och aktiv tillfällesdiktare. Kyösti Väänänen, "Johannes Henrici Flachsenius", Turun biippakunnan paimenmuisto $1554-I 72 I$, Studia Biographica 9, Helsinki: Suomalaisen Kirjallisuuden Seura, http://urn.fi/urn:nbn:fi:sks-thp-000655 (hämtad 24/II 2020).

30. Flachsenius, gravdikt i Lijk-Predikning öfwer [...] Hustru Maria Lorentzdotter Gertes [...] Jordefärd och Begraffning.

31. Culler, Theory of the Lyric, s. I86-I87.

32. Gerhardus Johannes Vossius, Elementa Rhetorica eller Retorikens grunder. Översatt och utgiven av Stina Hansson, Göteborg: Göteborgs universitet I990, s. I4; Hansson, 
retoriska genre av tal som tillfällesdikterna ansågs tillhöra, genus demonstrativum, alltså det lovprisande talet. I praktiken innebär lovprisandet att föremålet för dikten beskrivs på ett idealiserande sätt och prisas för egenskaper och dygder som var passande just för personen i fråga. ${ }^{33}$ Också klagandet och tröstandet skulle utformas så att det passade den avlidnas ställning. Medan gravdikterna tillägnade den ålderstigna Christina Bergenstierna berättar väldigt lite om henne som person, är dikterna som tillkommit till minne av Maria Lorentzdotter Gerdt betydligt mer detaljerade. Johannes Flachsenius beskriver henne som en idealisk maka och mor, kärleksfull, förståndig, och med ett sinne för affärer. Gravdikterna lovordar sina föremål för egenskaper som i allmänhet ansågs vara önskvärda hos en person av diktföremålets stånd och kön, och för kvinnornas del var dessa alltid knutna till hemmets och hushållets sfär. Flit, förstånd och intresse för affärer var önskvärda egenskaper hos en köpmanshustru. ${ }^{34}$ Adressaterna skildras så att de framstår som exempla, goda exempel på hur en person av adressatens kön och sociala rang ska vara. Som Ann Öhrberg konstaterat är tillfällesdikternas kvinnoideal ofta mer homogent, medan männen kunde framstå som exemplariska på flera olika sätt. ${ }^{35}$

De två dikterna till Christina Bergenstierna - den ena av Johannes Gezelius Nepos, den andra av hans tidigare informator Daniel Juslenius - är allmänt hållna och innehåller reflektioner kring livets förgänglighet. Döden framstår som önskad och efterlängtad för den fromma frun som redan tröttnat på det världsliga livet. Dikterna uttrycker beundran och uppskattning för hennes fasta tro och stoiska livsinställning. Medan dikterna till Christina Bergenstierna inte innehåller explicit klagande eller tröstande, har dessa en framträdande roll i dikterna till Maria Lorentzdotter Gerdt. Klagandet framhävs också $i$ andra dikter som hedrar minnet av personer som dött vid unga år, $\mathrm{i}$ vilka man tar fasta på tragiken i att en ung hustru dör och små barn blir moderlösa. Det här har att göra med tillfällesdiktningens sätt att

"Bröllopslägrets skald och bårens", s. 56-57; Sarasti-Wilenius, "Henkilökirjallisuus", s. $234-236$.

33. Gustafsson, "Litteratur och miljö", s. IIg.

34. Kekke Stadin, Stånd och genus i stormaktstidens Sverige, Lund: Nordic Academic Press 2004, s. 249-25I, 261.

35. Öhrberg, Vittra fruntimmer, s. I48-I49. 
beakta föremålets sociala tillhörighet. Enligt principen om decorum bestämdes dikternas stil, form och innehåll av personens kön, ålder och sociala status. Decorum påverkar också diktens sätt att behandla känslor. Medan dikter till män med höga positioner i allmänhet var förbehållsamma i fråga om att ge uttryck för sorgen och saknaden, var det däremot på sin plats att kvinnor och barn sörjdes på ett känslosamt sätt. Dessa dikter strävade uttryckligen efter att framkalla medlidande hos publiken. ${ }^{36}$

Medan luctus, klagandet, på samma sätt som lovprisandet påverkas av föremålets sociala tillhörighet, har tröstandet, consolatio, en mer allmän karaktär. ${ }^{37}$ I Johannes Flachsenius gravdikt till Maria Lorentzdotter Gerdt får klagandet mest utrymme, men dikten avslutas med en lovprisning av den avlidna och tröstande ord till maken. Enligt dikten kommer hela staden att berömma hennes minne, och Gud kommer att hjälpa den sörjande:

Det hugne tigh der näst: at heela Staden thenne

Förtäljer hennes Dygd / och weet berömma henne.

Det hoos tigh sargat är / det will Gudh heela wäl

Och frögda tigh igen både til Lijf och Siäl. ${ }^{38}$

\section{GRAVDIKTERNAS TALARROLLER}

Förutom olika former av tilltal använder sig gravskrifterna också av ett antal olika talarroller. I sin omfattande studie om den svenska bröllopsdiktningen har Stina Hansson visat att talarjag som är identiska med diktarens biografiska jag blir betydligt vanligare under I70o-talet, samtidigt som de förr så vanliga rolljagen börjar försvinna. ${ }^{39}$ Bröllopsdikterna utformades allt oftare som lyckönskningar och hälsningar från skribenten till mottagaren, inte som tal av fiktiva rolljag. Liknande jämförande studier om gravdikternas talare har inte

36. Hansson, "Bröllopslägrets skald och bårens", s. 44-46; Hansson, Från Hercules till Swea, s. 55-59.

37. Hansson, "Bröllopslägrets skald och bårens", s. 57-58.

38. Flachsenius, gravdikt i Lijk-Predikning öfwer [...] Hustru Maria Lorentzdotter Gertes [...] Jordefärd och Begraffing.

39. Hansson, Svensk bröllopsdiktning, s. 483 . 
gjorts. I mitt material ingår såväl dikter där talaren framhäver sin vänskap eller sitt släktskap med föremålet, dikter där talarens identitet inte kan fastställas och dikter där den som talar är någon annan än författaren. Till exempel kan Johannes Gezelius Nepos identifieras som talare i dikten över Christina Bergenstierna genom att föremålet i dikten kallas farmor. Men det är inte heller ovanligt att skribenten låter andra personer ta till orda. En sådan dikt är skriven av den tioåriga gossen Daniel J. Unger till minne av hans mor Sara Danielsdotter år I657. I dikten är det den döda modern som talar, och sonen Daniel undertecknar dikten på följande sätt: "Således uti sijn Saliga Kära Moders nampn tröstar sin elskelige effterblefne bedröfwade Kära fader och der jempte sigh sielfwan DANIEL J. Unger Defunctae Filius." ${ }^{40}$ Som här anges, handlar det alltså om att skribenten uppträder i någon annans namn eller låter någon eller något annat ta över talarrollen.

Idén om att låta någon annan ta till orda har sitt ursprung i retorikens tradition. Begreppet prosopopoeia syftar på ett framställningssätt där en icke närvarande person framställs som närvarande, eller där något stumt och livlöst uppträder som talare. ${ }^{41}$ Enligt Gerhardus Johannes Vossius bok Elementa Rhetorica, som hörde till r6oo-talets mest använda läroböcker i retorik, går prosopopoeia ut på att föreställa sig att de döda talar,"som om de vore i livet, eller de frånvarande, som om de vore närvarande". ${ }^{42}$

Ett närbesläktat begrepp är sermocinatio som syftar på tal som läggs i munnen på någon viss person och formuleras så att det speglar personens karaktär. ${ }^{43}$ I retoriken har dessa två figurer använts dels för att förklara eller förstora något, dels som medel för karaktärsbeskrivning. Tanken var att talet fick spegla talarens personlighet och karaktärsdrag. ${ }^{44}$ Ett liknande syfte hade ethopoeia, också ett av retorikens grepp som gick ut på att imitera någon annans sätt att tala eller skriva. ${ }^{45}$

40. Lijk-Predikan Widh fordom Ehreborne/Gudhfruchtige och Dygdesamme Hustrws H. Sara Daniels Dotters [...] Begrafning, Åbo: Peder Hansson 1657.

4I. Ad Herennium. De ratione dicendi ad C. Herennium, översatt av Birger Bergh. Åstorp: Rhetor förlag 2005, IV:66.

42. Vossius, Elementa Rhetorica, s. 33 .

43. Ad Herennium, IV:65-66.

44. Vossius, Elementa Rhetorica, s. 33.

45. Daniel Möller, Rolldiktningens poetik. Olof von Dalins experimentella tillfällesdiktning, Göteborg \& Stockholm: Makadam förlag 2019, s. 38-39. 
Ur dessa retoriska formler utvecklades under i7oo-talet den så kallade rolldikten, där en karaktär ställs i centrum av dikten genom att denna själv uppträder som talare. ${ }^{46} \mathrm{I}$ rolldikterna är spänningen mellan det uttalade och det outtalade, mellan diktens mimetiska och retoriska plan, ett centralt element. ${ }^{47}$ De gravdikter till kvinnliga adressater som analyseras här innehåller inga direkta motstridigheter mellan dessa två plan. Däremot finns det likheter mellan rolldiktens och gravdiktens sätt att använda sig av sermocinatio och prosopopoeia för att anspela på läsarens känslor och väcka medlidande.

Vid sidan om retoriken finns det också andra förebilder för dikter där den döda uppträder som talare. Bland annat i psalmdiktningen ingår texter som är utformade som den dödas tal. ${ }^{48} \mathrm{I}$ finsk psalmdiktning blir denna tradition utpräglat feminin under I70o-talet, i och med att talaren i många fall är en kvinna. ${ }^{49}$ De dikter jag härnäst kommer att se på skiljer sig från både rolldikterna och psalmerna genom att de överger monologen och utvecklas till en dialog mellan makarna. I den tidigmoderna litteraturen var dialogen ett framställningssätt som kunde användas till mycket. Dialogen var ett naturligt inslag i drama, men också religiösa skrifter, exempelvis katekeser, filosofiska utläggningar, politiska pamfletter och poesi kunde ta formen av en dialog. ${ }^{50}$ Dialogformen hade också tidigare använts i dikter om döden. I många dialoger mellan döden och människan är det en yngling som representerar livet. ${ }^{51} \mathrm{I}$ de dikter jag kommer att behandla utspelar sig

46. Enligt Daniel Möller var Olof von Dalin den första svenska diktaren som skrev rolldiktning i större omfattning. I Dalins rolldikter är rolljaget författarens alter ego, alltså inte en fiktiv karaktär helt avskild från författaren. Möller, Rolldiktningens poetik, s. 40-4I.

47. Daniela Silén, Rolldiktens jag. Aspekter på svenskspråkiga rolldikter från Bellman till Runeberg, Helsingfors: Helsingfors universitet 20I7; Katja Seutu, Olla elävän sanat. Roolirunon laji Maila Pylkkösen teoksessa Arvo, vanhaäiti puhuu runonsa, Helsinki: Suomalaisen Kirjallisuuden Seura 2009.

48. "I träck och sand och swart muld" i sångboken Liber Cantus (I620) är den äldsta av dem. Fehrman, Diktaren och döden, s. I35.

49. Pirjo-Liisa Niinimäki, "Kuolemaanvalmistusvirsi naisten runoutena", Liisa Enwald \& Tuula Hökkä (toim.), Virren virtaa. Veisattu runo ennen ja nyt, Helsinki: Kansanvalistusseura 20IO, s. II-43.

50. Dorothea Heitsch \& Jean-François Vallée (eds.), Printed Voices. The Renaissance Culture of Dialogue, Toronto: University of Toronto Press 2004.

51. Fehrman, Diktaren och döden, s. II8, I9I, 220, 323. 
den verkliga interaktionen mellan det äkta paret, trots att också döden ibland tilltalas. Ur retorikens synvinkel är det fråga om att kombinera två olika former för fiktivt tal: sermocinatio, som utgör grunden för makens tal, och prosopopoeia, som den döda hustruns tal bygger på. Döden uppträder ändå inte som talare, vilket innebär att dialogerna făr en annan prägel än dialogerna med döden. Dikterna är nämligen förutom gravdikter också kärleksdikter, och kärleken mellan makarna har en framträdande roll i dem.

\section{FrÅn MONOLOG TILL DIALOG}

Gustavus G. Gronovius dikt till Maria Lorentzdotter Gerdt börjar med makens klagan över hustruns plötsliga bortgång:

Ach! hiertans Ångest stoor / ach! Suckan / Wee Älende Som nu uthi migh boor / och moot Förmodan hände! Medh sorgeligit Sinn iagh ey uthföra kan Hoo är nu Trösten min? tröst fins hoos ingen Man. Ty Dödh then snöde Gäst / hoos migh sig sökt Inrymme Och har föröfwat mäst sitt Tyrannij thet grymme. Bortröfwandes min Roos / Min endest hiertans Flam Min ädleste Turkoos uthur mitt Skööt och Fampn.

När hwar sin Maka käär i Liufligheet tiltalar

Sij! iagh tå ensligh är / har ey hwem migh hugswalar.

Mitt Huus til saknad stoor / mist haar sitt endest Stödh

Och Klagan qwar nu boor / wee tigh tu grymme Dödh. [... $]^{52}$

Förlusten av hustrun framstår som en förlust av en samtalspartner: "När hwar sin Maka käär i Liufligheet tiltalar / Sij! iagh tå ensligh är / har ey hwem migh hugswalar." Hustrun sägs vara den som kan trösta. Samma tanke återkommer i diktens avslutning, där mannen önskar att han och de små barnen kunde få se och samtala med den döda. Ett sista samtal med den bortgångna framstår som det enda som kan skänka tröst.

52. Gronovius, Klage-Grååt Öfwer [...] Hust. Maria Lorentz Dotter Gerdt. 
At wij Ehr finge see / en gång i thenne Werld.

Och niuta Ehrt Samtaal / tå skulle min Sorg lugnas.

Och lindras thetta Qwahl / ja Barnen åter hugnas.

Men thet är migh förmeent / i thenne onde Tijdh /

Thet önska är förseent: thet heter: Bijdh och lijdh!"53

När maken talar till sin hustru i dikten förväntar han sig naturligtvis inte att hon ska höra honom. Eftersom hon redan är död kommer hans önskan om ett sista samtal för sent. Det här innebär att talsituationen i dikten är monologisk - maken talar för sig själv. Till skillnad från gravdikter som tilltalar den avlidnes vänner och anhöriga använder sig dikter med tilltal till den döda av apostrofering; de tilltalar någon som är frånvarande och inte kan svara. Enligt Vossius Elementa Rhetorica innebär den retoriska figuren apostrof att "man vänder sig med sina ord till någon eller något annat än talets åhörare" ${ }^{54}$ Apostroferingen gör den tilltalade till adressat och drar henne dessutom in i en kommunikativ situation. Oberoende av om den tilltalade är en person, ett föremål, en naturkraft eller ett fenomen, gör tilltalet objektet till subjekt, någon som man kan tilltala. Apostrofen skapar alltså dialogicitet samtidigt som det i talsituationen finns en medvetenhet om att den som tilltalas inte är närvarande och inte kan delta i kommunikationen. ${ }^{55}$

I de exempel som citerats riktar sig det apostrofiska tilltalet främst till döden och till den döda. I båda fallen fungerar apostrofen som ett medel för att levandegöra den tilltalade. Döden, någonting abstrakt och svårt att greppa, personifieras genom tilltalet till en fiende med mänskliga drag och attribut. ${ }^{56} \mathrm{När}$ den döda apostroferas handlar det främst om att illustrera frånvaron av den älskade makan. Apostrofering belyser motsatsen mellan närvaro och frånvaro. I retoriken och i lyriken har greppet använts som ett sätt att uttrycka och uppväcka

53. Ibid.

54. Vossius, Elementa Rhetorica, s. 33.

55. Jonathan Culler, "Apostrophe", Jonathan Culler, The Pursuit of Signs: Semiotics, Literature, Deconstruction, Ithaca: Cornell University Press I98I, s. I4I-I43, I46.

56. Fehrman, Diktaren och döden, s. 78. 
känsla. ${ }^{57}$ I moderna elegier fungerar det apostrofiska tilltalet som ett sätt att bibehålla kontakten och känslobanden till den avlidna. ${ }^{58}$

Jonathan Culler ser apostrofen som ett sätt att framhäva själva talakten i dikten. Då fungerar den också som en motkraft till narrativa strukturer och tidsstrukturer. ${ }^{59} \mathrm{Genom}$ att betona talakten är det talandets nu som framhävs - inte nuet som en stund i ett händelseförlopp. I dikter som behandlar förlust associeras det förgångna med den älskades närvaro och nuet med hennes frånvaro. Med apostrofens kraft kan diktens talare omkullkasta temporaliteten och mana fram den frånvarande, så att hon blir närvarande i talakten. Den temporalt bestämda närvaron och frånvaron ersätts med en apostrofisk, diskursiv närvaro och frånvaro.

Dialogdikterna skiljer sig från många andra apostroferande gravdikter genom att de inte stannar kvar i en apostroferande talsituation. Till exempel i en dikt till den unga borgmästarhustrun Catharina Wernle, skriven av studenten Erik Sundelius, uppträder såväl Catharina och hennes make som deras barn som talare, men trots att de tilltalar varandra uppstår ingen dialog mellan de olika talarna. ${ }^{60}$ Ibland utvecklas talsituationen emellertid till en dialog $\mathrm{i}$ och med att den tilltalade svarar på tilltalet. Genom sin användning av en fiktiv talarroll och en fiktiv talsituation positionerar sig dikterna i en fiktiv värld, vilket skapar förutsättningen för att det monologiska talet kan övergå i en dialog. Det som talaren i dikten till Maria Lorentzdotter Gerdt hävdar att inte kan ske eftersom det är för sent händer faktiskt: den döda svarar, och förundrar sig över den "sorgesång" hon blivit åhörare till. Också hon hänvisar till forna samtal mellan makarna då hon tar avsked av sin man:

57. Ad Herennium, IV:22; Culler,"Apostrophe", s. I38.

58. Anna Hollsten, "Puhetta kuolleelle. Puhuttelu ja kiintymyssuhteen jatkuminen Paavo Haavikon, Aale Tynnin ja Anja Vammelvuon elegioissa", Kirjallisuudentutkimuksen aikakauslehti Avain 20I7:I, s. 6-2I, https://doi.org/I0.30665/av.66Igo.

59. Culler,"Apostrophe", s. I50-I52.

6o. Erik Sundelius, gravdikt i Klago Schrifft öfwer [...] Chatarina Wernlers [...] H. Nicolai Lietzens Wälförordnat Konungzlig Borgmästar uthi Åbo Elskelige kära makas hastelige och oförmodelige doch gudelige och salige bortgång ifrån denna usla Jämmerdalen [...], Åbo: Peder Hansson 1657 . 
Medh Barnen små leff säll / för förra Echtaband Biuder iagh fahra wäl och räcker Ehr min hand. Haff' myckin Ähra / Tack för troligit Bemöthe.

För ett liufligt Snack / erhållit i Ehrt Sköthe. ${ }^{61}$

I svaret upprepas tanken om det"liufliga" samtalet mellan äkta makar som en källa till glädje och ett uttryck för den äktenskapliga sämjan och kärleken.

I dikten över den adliga Beata Margareta Uggla sker övergången från makens monolog till dialog mellan makarna på ett liknande sätt. Dikten, som är skriven av Beatas yngre bror Claes Uggla, beskriver hur den döda blir som uppväckt av att höra hur hon sörjs:

Hwad är för Sorg och Lååt / som för min Öron ställes

Ja och så mycken Grååt / titt Tåårar för migh fälles

Öfwer min hädanfärd / och öfwer min Bortgång

Hwad hielper blifwa här / bland ijdel Sorg och Twång

Begif Eer derför ey til Grååt och så stor Smerta

Ty det i sörja måtj / der af röres mitt Hierta! ${ }^{62}$

Ändringen i talsituationen anges ofta med latinska underrubriker. ${ }^{63}$ Makens tal rubriceras ofta som "Makens klagan", hustruns tal som "Den avlidnas svar", eller, som i dikten till Margareta Knutsdotter,"Den avlidna svarar med glädje”. Vissa dikter har flera delar. Till exempel dikten till Beata Margareta Uggla är fyrdelad: makens klagan över den grymma döden åtföljs av barnens klagan över moderns död, och först därefter följer den dödas svar och farväl. I dikten till Catharina Wernle, hustru till borgmästaren i Åbo, åtföljs makens och den döda hustruns dialog av en "Votum Consolatorium", en tröstande önskan av en tredje talare, som inte är ett rolljag och som inte namnges eller identifieras.

6r. Gronovius i Klage-Gråăt Öfwer [...] Hust. Maria Lorentz Dotter Gerdt.

62. Claes Uggla, gravdikt i Sorge-Fahna/Öfwer den Edle och Wälborne Fru Beata Margareta Uggla / Til Nygård och Brötorp, Åbo: Johan Winter r69o.

63. Till exempel: Maritus dolens loquitur och Defuncta gaudens respondet i dikten till Margareta Knutsdotter, Mariti vox querula och Responsorio Defunctae i dikten till Maria Lorentzdotter Gerdt, Lamentatio Mariti Relicti och Responsio Beate Defunctae i dikten till Anna Walstenia. 
Gravdikterna tillämpar en dialogform som är rätt stel; talarna framför sina tal var för sig och replikerna vävs inte in i varandra. ${ }^{64}$ Trots stelheten är dialogiciteten och interaktionen i dikterna ändå tydlig, i och med att hustrun i sitt tal svarar på mannens tal. Till sin struktur påminner dikterna i viss mån om Höga visan, utformad som en dialog mellan två röster som kompletteras av en kör. Det är troligt att den bibliska kärleksdialogen är en förklaring till att dialogformen använts i dikter till döda hustrur. Där bruden och brudgummen i Höga visan talar om samma sak, samma känsla, är det utmärkande för dessa gravdikter att det emotionella innehållet i diktens olika delar har olika karaktär beroende på talaren: makens tal uttrycker sorg och saknad, hustruns tal hoppfullhet och tillförsikt.

\section{KÄRLEK OCH SORG：MAKENS KLAGAN}

I de dialogformade dikterna går makens tal ut på att beklaga dödsfallet. Klagandet dominerar, men dikten kan också innehålla indirekt lovordande av hustrun. Många dikter börjar med ett tilltal till döden, som anklagas för att ha fört bort en kär vän och maka. Så här tilltalas döden i en dikt av studenten Johannes Danielis Ekeroot, ${ }^{65} \mathrm{i}$ gravskriften till Catharina Wernle. ${ }^{66}$ Talaren i dikten är hennes make:

Ach Dödh! ach Dödh! hwad sorgh och grååt

Hwadh jämmer och så plågha

Tu hafwer migh tilhanda fått

Att jagh eij kunde äga

Min hiertans wen och maka kiär

Som sigh så wänligh tedde

Ehwadh jagh war när eller fierr

Altijdh mitt hierta glädde

Derför jagh migh så skickar här

Som Dufwan söria plägar

64. Jfr Fehrman, Diktaren och döden, s. 323 om Lasse Lucidors dödsdialog.

65. Kyösti Väänänen,"Johannes Danielis Eekeroot”, Turun hiippakunnan paimenmuisto I554-I72I, Studia Biographica 9, Helsinki: Suomalaisen Kirjallisuuden Seura, http:// urn.fi/urn:nbn:fi:sks-thp-000507 (hämtad 24/II 2020).

66. Om Catharina Wernle och hennes äktenskap, se Veli Pekka Toropainen, 39 tarinaa I6oo-luvun turkulaisnaisista, Turku: Turun museokeskus 2019, s. 53-59. 
När hon mister sin maka kiär

Sitter på torra greenar. ${ }^{67}$

Maken inleder sitt tal med känslofyllda utrop som anger den emotionella tonen i dikten och riktar tilltalet till döden. Apostroferingen av döden får ofta en anklagande ton och kan ses som ett sätt att ge uttryck för vrede och frustration, känslor som vid sidan om sorg och saknad förknippas med förlusten av en nära anhörig. Det är dödens fel att talaren mist sin maka: "Hwadh jämmer och så plågha / Tu hafwer migh tillhanda fått."

Indirekt beskriver dikten också hustrun och talarens förhållande till henne. Talaren jämför sig med en duva som sörjer sin maka. Duvan var sedan antiken känd som en kärlekssymbol. I Höga visan är duvan en symbol för bruden, och turturduvans röst förknippas med våren, som är tiden för naturens men också kärlekens uppvaknande. ${ }^{68}$ Den ensamma sörjande duvan på den torra grenen i dikten till Catharina Wernle betecknar slutet på kärlekens tid och slutet på äktenskapet. Duvor förekommer också i en av dikterna till Maria Lorentzdotter Gerdt, där både den sörjande maken och den döda hustrun liknas vid en duva. ${ }^{69}$ Duvsymboliken och själva dialogformen, ifall den tolkas som en hänvisning till Höga visans dialog, sätter fokus på känslobandet mellan makarna. Den kärlek som duvorna representerar är frikopplad från de samhälleliga, religiösa, sociala och ekonomiska aspekterna av äktenskapet som var relevanta för I6oo-talets män och kvinnor. Ibland anspelar gravdikterna också på bröllopet som övergångsrit. Duvdikten i gravskriften till Maria Lorentzdotter Gerdt åtföljs av en dikt som beskriver hur bröllopets glada musik tystats av sorgen. ${ }^{70}$

67. Johannes Danielis Ekeroot, gravdikt i The Christrognas åtrå Eller Een lijten uthleggning $[\ldots]$ wedh H. Catharina Wernlers [...] begrafningz Process, Åbo: Peder Hansson I657.

68. Höga visan 2:12, 2:14, 5:2.

69. "Hwi sitter Dufwan nu och sörjer så sin Maka?", gravdikt av Johan Hinnersson Schefer den yngre, systerson till Herman Thorwöst, i Lijk-Predikning öfwer [...] Hustru Maria Lorentzdotter Gertes [...] Jordefärd och Begraffning.

70. "Jagh troor Fioler nu the tiena eij at låta / När Döden hafwer skildt the Wänner karsk och såta / Music och annor Speel / Regal och Pijpor all / The stämme aff sin Thon / och sörje detta Fall." Dikt av P. Schefer, en annan systerson till Herman Thorwöst. Ibid. 
För kvinnornas del hör hänvisningar till bröllopet ihop med dikternas sociala decorum och det faktum att kvinnorna i första hand hedras som hustrur och mödrar. Att gravdikterna anspelar på bröllopet framhäver naturligtvis också tragiken i dödsfallet och livets plötsliga skiftningar. Den som i ena stunden varit en strålande vacker brud och föremål för glada bröllopsdikter, är i den andra ett blekt lik och föremål för en gravskrift.

Som redan framkommit är apostroferingen, tilltalet av en ickelevande och frånvarande, också ett sätt att framhäva talarens ensamhet och avsaknaden av mänsklig kontakt. Ibland vet talaren inte vad han ska säga och vem han ska vända sig till.”Ach! ach! hwad skall jag nu tala? / Hwem är som mig månd' hugswala? / Borta är min bästa Wän”, inleder talaren i dikten till Anna Walstenia, hustru till kyrkoherden i Loimijoki, sitt tal. Talaren önskar att hustrun ännu kunde stanna kvar hos honom och avslutar dikten med en fråga: "Hwij min Wän will tu så hasta? / Och i ensamhet mig kasta / Uti diupa Sorgen qwar."71

Också i dikten till Margareta Knutsdotter, hustru till kyrkoherden i Kronoby, kommer sorgen till uttryck som villrådighet och ovisshet. Den första strofen är formulerad som en bön: talaren vänder sig först till Gud och därefter till sin döda hustru. Dikten, som är skriven av Magnus G. Westzynthius, kapellan i Brahestad, är för övrigt den enda av de dialogformade dikterna i materialet som har en melodihänvisning och en strofisk struktur. Dikten heter "Een Sorgwijsa" och den ska sjungas "under den Thon JESU Högsta Glädie". ${ }^{72}$

I.

Ach! min högsta Fadher /

$\mathrm{Nu}$ är iagh beladder /

med een hiertans Sorg /

Thet most iagh besinna

Tu kan bäst förminna /

71. Matthias Fontelius, gravdikt i The Trognas Fördolde Lijffoch Dödz Winning i Christo: Uthi en Christelig Lijk-Predijkan När [...] Pastorskan Anna Walstenia [...] beledsagades till sin Sofwekammar [...], Åbo: Henr. C. Merckell 1706.

72. Magnus G. Westzynthius,"Een Sorgwijsa", Loetitia (sic) Justorum Perpetua Eller The Rättferdigas stadiga och Ewiga Glädie hwar om En Christelig Lijkpredijkning är hållen [...] öfwer [...] Den fordom ähreborne myckit heder Dygdesamme och Gudfruchtige Matrona [...] H. Margareta Knutszdotter, Stockholm: Ignatio Meurer I668. 
Tu min Fasteborgh.

Sij then tu migh gifwit haar

Ögnalusten frå migh draar /

Ey kan hon sigh meera röra /

Ach hwad skal iaagh göra!

2.

Ach tu min Wän bästa /

Thenne Sorgen nästan /

migh i Grafwen föör /

Jagh är åldrigh blifwen

Och nu öfwergifwen

Af tigh min Wän käär

Har iagh icke elskat tigh?

Har tu icke lofwat migh /

At lefwa och boo tillsamman /

Medh stoor Frögd och gamman.

3.

Men hur såndat sannas

Seer nu een och annan

Thet iagh måste boo

Och nötha min Dagar

Doch som Gudh behagar

Medh mycken Oroo

Ingen är som frågar tigh

Ingen är som swarar migh

Heela natten måst iagh waka

Så är iagh försakad. ${ }^{73}$

"Ach hwad skal iaagh göra!" utbrister talaren i slutet av den första strofen. Hela hans tal präglas av en känsla av att vara borttappad och osäker på hur han ska hantera situationen. Talaren ställer frågor som förblir obesvarade: "Har iagh icke elskat tigh? / Har tu icke lofwat migh / At lefwa och boo tillsamman / Medh stoor Frögd och gamman." Frågorna innehåller en antydan om att maken känner sig sviken av hustrun, som vid sin död lämnat honom ensam. Dikten avslutas

73. Ibid. 
med att talaren ändå medger att allt som sker följer Guds vilja. Han tar avsked av sin hustru med en önskan om att Gud ska ge henne mycket glädje och trösta honom i sorgen. I allmänhet karaktäriseras de sörjande makarnas tal av utsiktslöshet. De blickar inte framåt till tiden som ska komma, utan deras tal fokuserar på glädjen i det förgångna och på det tröstlösa nuet.

Att gravdialogerna så ingående beskriver skillnaden mellan tiden före dödsfallet och tiden efter makans död hör ihop med de retoriska medlen att väcka medkänsla. Enligt Vossius väcker talet medkänsla till exempel genom att visa hur lidande och olycka drabbar någon som inte gjort sig förtjänt av motgångar. Detta kan förstärkas genom att "jämföra den lycka någon förut åtnjöt med den nuvarande olyckan". ${ }^{74}$

Ofta tar dialogdikterna fasta uttryckligen på den förändring som dödsfallet innebär. Den som man tidigare delat sitt liv med finns inte längre kvar. Hemmet känns tomt och tyst och mannen är nu ensam ansvarig för familjen och hushållet. Beskrivningen av det äktenskapliga livet får stort utrymme i dikten till Beata Margareta Uggla. Det beskrivs som lyckligt och harmoniskt, fullt av"Kärleek Lust och Sämmiä”. I dikten förekommer många av gravdikternas mest typiska dödsbilder; döden framställs som en grym tyrann, en hård gäst som oönskad kommer på besök och som en jägare som skjuter "skarpa Pijlar" som ingen kan komma undan ${ }^{75}$ :

Ach! Ach! O hårda Dödh / tu migh grymmer worden Migh har du fördt i Nödh som så fält har til JOrden. Then som migh såtast war / och den iagh hölt så kär Ett wänligt hierta bar hon til migh fiärr och när.

Medh den jagh lefwa tänckt i Kärleek Lust och Sämmia

Den har du från migh länkt / min Sorg sålund befrämia

Dess Lijfz-Tidz ädla Åhr i denne Wärld med migh

Tu tigh fast grymmer teer och är migh rätt oblijdh.

Medh den iagh lefwat haar i hiertans Frögd och Fängna

Den migh i allom Tijdh så kärligen har hägna.

Dhen wänligh stälte sigh och war i hiertat week

Medh den du drammat Strijd och giort i Ögon bleeck.

74. Vossius, Elementa Rhetorica, s. I3.

75. Om döden som jägare, se Fehrman, Diktaren och döden, s. 78. 
Så att iagh qwijda måst Ach! Sorg och Wee! iagh roopar

Sorg röör mitt Hierta fast / ty wij ey meer tilhoopa

Fåå boo tilsammans häär / min Maaka är nu döö

Hon är nu skuten hårdt af dödzens skarpa Pijlar

Thet gör mit Hierta sårt stoort qwahl uthi migh ijlar

Ty iagh nu seer för migh / på Båren wara lagd

Min Wän och Maka sij: iagh är nu heel försagd.

O Dödh tu hårda Gäst tu äst Tyrannen grymma

Hwars Ståål och hårda Lagh ey någon kan undrymma

Ja ja din Båga sträng din Pijl och skarpa Dart

Ha henne redt en Säng i diupa Jorden snart.

Förbleknad är hon fast / för kålnat och dess hierta

I stycken brustit har / ach! Wee ach Sorg och Smerta

Alt alt är migh förmeent stoor Ängslan i migh boor

Min Lust och Frögd är wänd i Ängslan och Oroo. ${ }^{76}$

I dikten ser talaren sin döda maka ligga på båren och klagar över att de inte längre får leva och bo tillsammans. Livet med hustrun framstår som ett liv fyllt av glädje och lycka och allt detta går talaren miste om vid hennes död. Förändringen är plötslig och total: "Min Lust och Frögd är wänd i Ängslan och Oroo.”

Att nämna känslor som sorg, oro, smärta och ängslan, som i dikten ovan, är ett sätt att skapa pathos. ${ }^{77}$ I Elementa Rhetorica förknippar Vossius pathos med affekter eller sinnesrörelser. ${ }^{78}$ Känsla uttrycks också genom exklamationer: "Så att iagh qwijda måst Ach! Sorg och Wee! iagh roopar." Dikten innehåller utrop och anger att det uttryckligen handlar om rop och kväden, inte till exempel om tankar och suckar. Dikterna beskriver också yttre tecken på sorgen samt handlingar och gester som uttrycker sorg. Gravskrifternas talare kvider, klagar, jämrar sig och gråter strida strömmar, förtvinar, bleknar och vakar nätterna igenom. Hyperbola uttryck som förstorar och överdriver känslan hör till tidens litterära estetik. ${ }^{79}$

76. Uggla, gravdikt i Sorge-Fahna / Öfwer den Edle och Wälborne Fru Beata Margareta Uggla.

77. Öhrberg, Vittra fruntimmer, s. I25.

78. Vossius, Elementa Rhetorica, s. I2

79. Ibid., s. $25^{-26 .}$ 
Dikten till Beata Margareta Uggla beskriver i detalj själva talsituationen och diktjagets upplevelser och känslor i den specifika stunden. Dikten nämner känslor och beskriver sätt att uttrycka känsla. Det är helt uppenbart att känslobeskrivningar som denna är skrivna med läsaren i åtanke; dikterna strävar efter att få läsaren att känna sorg och medkänsla med talaren, till exempel genom att framhäva motsatsen mellan den tidigare lyckan och den nuvarande olyckan. Makens tal i dialogdikterna uttrycker sorg på ett instruktivt och åskådligt sätt, vilket ger talet i dikten en teatralisk prägel: så här ska sorg kännas, så här ska sörjandet se ut. Talet är utformat på ett sådant sätt att det ska vara möjligt för läsaren att leva sig in i situationen och fungerar därmed som ett affektivt skript, som ett redskap då man ägnar sig åt känslan sorg. ${ }^{80}$

\section{DEN DÖDA SVARAR OCH TRÖSTAR}

Medan den första delen i flera dikter, makens tal, är en reaktion på hustruns död, är hustruns svar en reaktion på mannens sorg. Det här framgår också av dikternas rubriksättningar, där den dödas tal fått rubriken responsio, svar. Ofta har den dödas tal som uttalad avsikt att erbjuda tröst. I gravdikterna står de båda talarna för var sin känsla: maken för sorgen och tröstlösheten, den döda hustrun för hoppet och trösten.

Den referensram inom vilken gravdikterna skrevs och lästes präglades av I60o-talets lutherska ortodoxi. Det här påverkar naturligtvis dikternas uppfattning om döden och de känslor den väcker. Inom kristendomen innebär döden en seger för den avlidna, en hemkomst och ett evigt liv, medan döden för de efterlevande innebär en förlust som ger upphov till sorg och saknad. Tillfällesdiktarna var tvungna att balansera mellan dessa två motsatta aspekter av döden. I dialogdikten kunde både den tröstlösa sorgen och glädjen över det eviga livet uttryckas utan att diktaren behövde sammanjämka dem.

När de döda uppträder som talare resonerar de på olika sätt kring sorg och tröst i sina svar till maken. Ibland hänvisar talarna till förnuft och sakskäl när de uppmanar sina makar att sluta sörja. Ett argument

8o. Om affektivt skript, se McNamer, "The literariness of literature", s. I436. 
är att det är onödigt att sörja eftersom döden hör livet till och vi alla förr eller senare dör: "Hwad hielper ögon wååt / emot den grymma Dödh", sägs det i dikten till Beata Margareta Uggla. ${ }^{81}$ Förgängelsetanken, uppfattningen om jordelivets flyktighet och dess betydelselöshet, hör till gravdikternas återkommande inslag. ${ }^{82}$ I dialogdikterna förekommer den ofta i hustruns tal.

Sorgen var en naturlig reaktion på förlusten. Den som miste en familjemedlem förväntades sörja. Men för mycket sorg var inte bra, utan sorgen skulle vara rimlig. I "Een Sorgwijsa”, dikten till Margareta Knutsdotter, uppmanar den döda hustrun sin make att inte sörja omåttligt:

Så min hiertans Maka

At iagh ehr försakar

Och skilies ifrå

Låter edert Hierta /

Öfwermåttan smerta /

Intet öfwergåå / [... $]^{83}$

Känslor skulle tyglas och kontrolleras. Det stoiska inslaget i gravdikterna är rätt framträdande och ofta förenas idealet om stoisk oberördhet med kristna ideal som att finna sig i sitt öde. ${ }^{84}$ Uppmaningar att förlika sig upprepas i gravdikterna: "Geer' er' tilfredz min käre man / Gudi mån så behaga / Hans ord ey någon mootstå kan / Alt månd han wäl laga", tröstar hustrun sin make i en dikt tillägnad Sara Danielsdotter. ${ }^{85}$

I dikten till Margareta Knutsdotter är det maken som själv uttrycker en önskan om att kunna nöja sig med sin lott: "Jag wil tilj-

8I. Uggla, gravdikt i Sorge-Fahna / Öfwer den Edle och Wälborne Fru Beata Margareta Uggla.

82. Fehrman, Diktaren och döden, s. 45-50, I94.

83. Westzynthius, "Een Sorgwijsa" i Loetitia Justorum Perpetua [...] H. Margareta Knutszdotter.

84. Andrea Brady, English Funerary Elegy in the Seventeenth Century, Basingstoke: Palgrave Macmillan 2006, s. 37-43.

85. Johannes G. Alanus, gravdikt i Lijk-Predikan Widh [...] H. Sara Daniels Dotters elskelige Huusähras Begrafningh Tå hennes S. Lekamenu ti sin bwilocamar här $i$ Wijborgz Doomkyrckio nedersattes, Åbo: Peder Hansson I657. 
fredz blifwa / Och min Saak heel gifwa / Uthi Herrans hand; Han är then som sargar oss / Sorgen föör han och sijn koos / Han är then migh bedröwfar / Then och Glädien öfwar." ${ }^{86}$ I en annan dikt till Maria Lorentzdotter Gerdt framställs omåttlig sorg som rent ut sagt okristlig, något som är utmärkande för hedningar som inte tror på uppståndelsen. ${ }^{87}$

Det är intressant att diktens sätt att behandla sorgen framstår i en lite annan dager då man ser på hur den döda hustrun tilltalar sin sörjande man. Också i mannens tal har känslobeskrivningarna och känsloyttringarna en normativ karaktär. De visar hur man förväntades sörja, en hurdan sorg som var lämplig och var den sörjande skulle hämta tröst. Även om sorgen inte förnekas eller förminskas i hustruns svar, relativiseras den genom att mannens sorg sätts i förhållande till kvinnans glädje över det eviga livet. Ofta påminner gravdikterna om vikten av att inte låta sorgen ta överhand, och ibland uttrycker de också tankegångar om sorgens faror och det hot som sorgen kan utgöra mot människans tro på Guds försyn. ${ }^{88}$ Dikternas normförstärkande attityd är som tydligast just i den döda hustruns svar.

De döda som talar i dikterna gläder sig över att få komma till himlen, även om de också kan uttrycka sin sorg över att behöva lämna make och barn. I dikterna associeras himlen med stor glädje, tillfredsställelse och frihet från nöd och plågor. Att döden befriar människan från jordiska plågor återkommer ofta som en tröstande tanke. I dikten till Beata Margareta Uggla förekommer den både i den dödas tal till maken och i hennes tal till sina barn:

[...] O käre Barn min stillen er Tårar heeta

Som tilra å er Kinn / låt Er til Gråt ey weeta

86. Westzynthius, "Een Sorgwijsa", Loetitia Justorum Perpetua [...] H. Margareta Knutszdotter.

87. "Myckit sörja / af Sorg twijna / Sij! det är hedningars lagh / Som eij weta Christii Pijna / Eij troo Upståndelsens Dagh / Men wij hoppas i Gudz Rijke / Frijat blifwa allan Pust;/ Och der smaka all tillijte / Ewigh Frögd och hiertans Lust.” Det här är den andra dikten av Gustavus G. Gronovius över Maria Lorentzdotter, Gerdt tryckt i Lijk-Predikning öfwer [...] Hustru Maria Lorentzdotter Gertes [...] Jordefärd och Begraffning.

88. Brady, English Funerary Elegy, s. 4I-42. 
Jagh frij är från al Nödh / dödz Qwal ey röre migh /

Fast iagh är ligger död / iagh lefwer doch i Frijdh. ${ }^{89}$

Det som också uppfattas som trösterikt är hoppet om att få återse den döda i himlen. Så här tilltalar den döda hustrun sin make i dikten skriven till minne av kyrkoherdehustrun Anna Walstenia:

Hwem är som så swåra gråter?

Qwijder klagar ynckligt låter?

Wisserlig min Wän det är.

Hwarför fälles thesse Tårar?

Hwem har hiertat titt så sårat?

At tu sörjer min Wän kär.

Snart lär wij hwar annan möta

Uti himla-glädjen söta

Ther min Siäl nu frögdar sig.

Werlden war mig uselt näste

Här är Ewigt Frögde-fäste

Skynda hijt / min Wän och tig.

NU jag Talet mitt wil ända

Och til himbla-Sahl mig wända

Biuder tig sist farawähl. ${ }^{90}$

Medan makens tal fokuserar på det förgångna och på nuet, blickar den döda framåt. I hennes tal vidgas perspektivet från sörjandets nu till framtiden och evigheten: "Snart lär wij hwar annan möta / Uti himla-glädjen söta / Ther min Siäl nu frögdar sig." Talaren uppmanar sin make att skynda till himlen. Att ingjuta hopp om att återse varandra i livet efter döden hade moralisk och didaktisk betydelse. För de efterlevande gällde det att leva sitt liv så att hoppet om evigt liv och återförening i himlen inte gick förlorat.

Betydelsefullt med tanke på tröstens utformning är att förändringen från orörlig död kropp till odödlig själ ofta sker i dikten.

89. Uggla, gravdikt i Sorge-Fahna / Öfwer den Edle och Wälborne Fru Beata Margareta Uggla.

90. Fontelius, gravdikt i The Trognas Fördolde Lijff och Dödz Winning i Christo: Uthi en Christelig Lijk-Predijkan När [...] Pastorskan Anna Walstenia [...] beledsagades till sin Sofwekammar. 
I många gravdikter sker upptagningen från graven till himlen här och nu, i diktens presens, efter att den döda tagit avsked. Så här skildras händelseförloppet i en av dikterna till Maria Lorentzdotter Gerdt som hade dött i barnsäng:

Bäst som hon ängslas här / så stå Gudz Englar redigh

Och segna hennes Siäl / och säijä hon är werdigh

Medh Fostret at ingå / i Himmelsk Bröllops Saal

Undgå all Usellheet / och Werldzens Sorg och Qwaal. ${ }^{91}$

Deiktiska uttryck, som hänvisar till talsituationen, skapar en känsla av att det som dikten berättar om sker här och nu ("Bäst som hon ängslas här”). Ofta avslutas gravdikten med en skildring av den avlidna i himlen. I Gustavus G. Gronovius dikt över Maria Lorentzdotter Gerdt är det den döda själv som beskriver händelserna:

$\mathrm{Nu}$ Döden hugger til. Jesus min Siäl anammar

Then henne föra wil / til Saligheet / til Gamman.

Min Jämmer sigh haar ändt / afftorckad å min Tårar /

Fast Döden mig affhändt. Werlden iagh ey mehr wårar

Hoos Gudh i himmels Högd i heligh Engla Chor

Uthi stoor Lust och Frögd iagh nu lycksaligh boor. ${ }^{92}$

Ur tröstens synvinkel kan man anta att det har en viss betydelse att upptagningen till himlen skildras av rolljaget som upplevd verklighet, inte enbart som ett dogmatiskt påstående eller konstaterande.

\section{Att kommunicera KäNSLA}

Det utrymme som beskrivningen av sorgen får i dikterna antyder att de dialogformade dikterna inte i första hand är avsedda för den avlidnas närmaste familj, utan för en större läsekrets. Detaljerade beskrivningar av saknad, ensamhet och förtvivlan över att mista en

9I. Martinus Miltopaeus gravdikt i Lijk-Predikning öfwer [...] Hustru Maria Lorentzdotter Gertes [...] Jordefärd och Begraffning.

92. Gustavus G. Gronovius gravdikt i Klage-Gråă Öfwer [...] Hust. Maria Lorentz Dotter Gerdt. 
hustru eller en moder lindrar inte sorgen för dem som sörjer, men däremot kan de fă läsaren att känna sorg. Det här var antagligen precis vad beskrivningarna av sorg var avsedda att göra: att fă läsaren att känna sorg och medlidande med de sörjande och att skapa förståelse för deras situation.

Känslospelet i gravskrifterna följer ett bundet mönster som speglar den lutherska dödsuppfattningen och stormaktstidens syn på sorg och tröst. Dikterna går från sorg, förtvivlan, upplevelser av ensamhet och saknad till tröst, en visshet om att den avlidna har kommit till himlen och ett hopp om att få mötas igen i livet efter döden. Som affektiva skript är dikterna utformade så att läsaren får ta del av alla dessa känslor. Dialogen fungerar som ett instrument i denna process.

Diktaren som skriver en gravdikt i dialogform lever sig in i de båda rolljagens situation och deras upplevelser av sorg och saknad, samt återger deras sätt att uttrycka dessa känslor. Skribenten föreställer sig vad en viss person känner och upplever i en specifik situation. Dikterna strävar inte efter att återge verkligt tal, utan efter att beskriva talsituationer som kunde ha ägt rum men som trots detta är fiktiva. De distanserar sig från de verkliga historiska personerna som dikten handlar om dels genom att fiktionalisera historiska personer till rolljag, dels genom att framställa dem som exempla, förebilder, som genom sitt liv och sitt agerande kunde föregå som exempel för andra. Läsaren i sin tur lever sig in i författarens föreställning om rolljagens känslor i sin läsning av dikten.

Både skrivandet och läsandet av en gravdikt i dialogform kräver inlevelse, fantasi och medkänsla. Enligt Sarah McNamer har litteraturen förutsättningar att skapa beteendemässiga mönster just i och med att litteraturen är en arena för kreativitet. Litteraturen kan ses som en kognitiv och emotionell lek, där fantasin - förmågan att kunna föreställa sig sådant som är möjligt men inte finns - har en en central roll. ${ }^{93}$

Genom att beskriva samtalet mellan makar, mannens sorg och hustruns tröstande ord, har dikterna ett dubbelt fokus - de fokuserar inte enbart på sorgen och trösten utan också på den äktenskapliga kärleken. Äktenskaplig kärlek var en central dygd såväl för gifta kvin-

93. McNamer,"The literariness of literature", s. I436. 
nor som för män. ${ }^{94}$ Det är denna uppfattning om äktenskapet som dikterna ger uttryck för. I allmänhet lades stor vikt vid att hustrur skulle vara underordnade sina män, men i tillfällesdiktningen låg betoningen ofta, som i dialogdikterna, på den ömsesidiga kärleken. ${ }^{95}$

Trots sin tillfällesanknytning kunde gravdikterna alltså behandla ämnen som inte direkt hade med tillfället att göra, utan var allmänt intressanta och viktiga ur social och samhällelig synvinkel. I dialogdikternas fall handlar det om att ge mönster för att uppleva och uttrycka såväl sorg och tröst som äktenskaplig kärlek.

94. Stadin, Stånd och genus, s. 39, 48-55.

95. Öhrberg, Vittra fruntimmer, s. I50. 